\title{
Geologisk Set: Det sydlige Jylland - områder af national geologisk interesse
}

Anmeldt af geolog Per S. Sundberg, GeologiskNyt

Først i november udkom den 5. bog i serien "Geologisk Set". Denne gang er det det sydlige Jylland, der tages under behandling med en gennemgang af 26 lokaliteter af national interesse eller såkaldte Geosites.

UNESCO, De Forenede Nationers organisation for uddannelse, videnskab og kultur, har sammen med IUGS (International Union of Geological Sciences) forsøgt at registrere verdens mest betydningsfulde, geologiske og geomorfologiske lokaliteter, de såkaldte Geosites.

Ansvaret for at udvælge danske lokaliteter til Geosites ligger hos Nationalkomitéen for Geologi under Videnskabernes Selskab, og opgaven er herfra gået videre til Skov- og Naturstyrelsen i samarbejde med Dansk Geologisk Forening og Det Kongelige Danske Geografiske Selskab. Fredningsstyrelsen (nu Skov- og Naturstyrelsen) begyndte allerede 1984 at beskrive nationale geologiske interesseområder. Områderne blev foreslået af en arbejdsgruppe bestående af folk fra universiteterne, Danmarks Geologiske Undersøgelser (nu Danmarks og Grønlands Geologiske Undersøgelser) og Fredningsstyrelsen.

En række Geosites skal også være Verdensarvområder, og der har været planer om at udpege Vadehavet som et sådant.

\section{Bogen}

Bogen "Geologisk Set: Det sydlige Jylland" er den 5. i serien, hvor der tidligere er udkommet "Det nordlige Jylland", "Det mellemste Jylland", "Bornholm" samt "Fyn og Øerne". Indledningsvis skrives der, at "Formålet med bogen er at give bedre muligheder for at opleve, studere og forstå de geologiske processer, materialer og naturområder og forhåbentlig også opleve skønhedsværdien i landskabernes og lokaliteternes udtryksformer. Bogen er også ment som en vejledning ved administration og planlægning af det åbne land og som en guide til geologien i det sydlige Jylland".

\section{Indledning}

Bogens opbygning følger helt klassisk opbygningen i de øvrige bøger i serien. Efter et forord og en kort indledning forekommer der

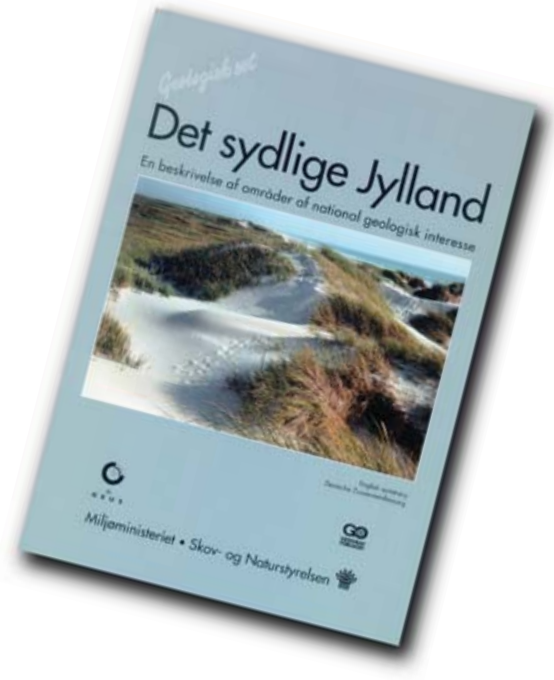

bes via sedimenttransport og opbygges af revler, der dannes på lavt vand og vandrer mod kysten, som revlerne smelter sammen med ca. hvert 10. år. Storm og vind bringer det tilførte sediment længere op på odden. Gennembrud i stormperioder danner overskylstunger på bagsiden af odden, og man kan sige, at pga. stigende havspejl ruller barrieren ind over sig selv.

Skallingen er dækket af store marskpartier, og øst for disse findes en såkaldt muddervade, der består af mere end $50 \%$ silt og ler.

For 500 år siden var Skallingen kun en beskeden bunke sand, og selve kystlinjen lå nordligere end i dag. På denne strækning fandtes et af datidens vigtigste fiskelejer, Sønderside.

en gennemgang af regionens geologiske udvikling i de seneste 25 millioner år, dog med hovedvægten lagt på (mellem)istiderne og tiden derefter. Beskrivelserne er fulgt op med mange farvestrålende, store som små, illustrationer. Ligeledes finder man også blå bokse med supplerende oplysninger. Dette kan fx være noget om myremalm i kirkebyggeri, danekræ, sedimentstrukturer eller andet. Disse blå bokse finder man også længere fremme $\mathrm{i}$ bogen.

\section{Profilerne}

Efter gennemgangen af regionens geologiske historie kommer man til beskrivelserne af de 26 udvalgte lokaliteter. Alle lokaliteter er Geosites, der har national og regional betydning, og nogle har endda international bevågenhed. Hver beskrivelse starter med en angivelse af lokalitetens geografiske placering i tekst, men er også angivet på et topografisk kort. Derefter følger den geologiske gennemgang af lokaliteten, som nok er det mest interessante for de fleste. Denne efterfølges af en omtale af stedets særlige værdi, og hvordan det bedst beskyttes.

Til de meget interesserede er der også angivet en liste med benyttet litteratur sidst $i$ beskrivelserne.

\section{Skallingen}

Af bogens mange lokaliteter er jeg selv specielt begejstret for nr. 87: Skallingen. Om det er, fordi jeg selv gennem mange år boede ud til Ho Bugt skal være usagt, men lokaliteten er præget af nogle facinerende processer. Skallingen er en "ung transgressiv barriereodde", kun 500 år gammel. Den ska-
Bogen er skrevet letlæseligt og er krydret med talrige, interessante illustrationer, som er medvirkende til, at man på intet tidspunkt synes, at det er kedelig læsning. Bogen lever til fulde op sit formål samt til den sædvanligt høje Geologisk Set standard og ville være en oplagt julegaveide til den geologisk interesserede.

Forfattere er Peter Gravesen, Peter Roll Jacobsen, Merete Binderup og Erik Skovbjerg Rasmussen, alle fra Danmarks og Grønlands Geologiske Undersøgelser. Bogen er udgivet af Miljøministeriet Skov- og Naturstyrelsen og Danmarks og Grønlands Geologiske Undersøgelse - $i$ samarbejde med Geografforlaget. Bogen kan fås ved henvendelse til Geografforlaget, Ruggårdsvej 55, 5000 Odense C, www.geografforlaget.dk. 188 sider, 216 kr. eks. moms. ISBN: 87-7702-400-1.

\section{Vidste du:}

*At du kan købe alle de tidligere, ikke-udsolgte numre (p.t. $58 \mathrm{stk}$.) for kun $300 \mathrm{kr}$. (ekskl. porto $57,50 \mathrm{kr}$.)?

\section{Eller}

*At du kan købe et klassesæt med 30 numre for $450 \mathrm{kr}$. (ekskl. porto 57,50 kr.)? 